\title{
A kritikai cselekvés új színterei
}

\author{
Kecskés Nóra \\ https://doi.org/10.51624/SzocSzemle.2018.1.10
}

\begin{abstract}
„A kritikai cselekvés új színterei” blokkban négy előadó mutatta be kutatásait, amelyek valamilyen szempontból a részvételiség és cselekvés fogalmait állítják vizsgálódásuk középpontjába. Az előadások utáni beszélgetést Vigvári András moderálta.
\end{abstract}

\section{Hiányzó pillanatok a színházból}

A blokk első előadását Oblath Márton tartotta a SajátSzínház.org akciókutatásairól. A többféle performatív beavatkozást összefogó kísérletsorozat $A$ hiányzó padtárs címú 2012-es társadalmi színházi programjukból nőtt ki; ma a „padtársak” mellett a baranyai Siklósbodony lakói és egy szomolyai közmunkásokból álló női csoport tagjai múködnek közre az előadásokban.

A SajátSzínház programjai a részvételi akciókutatás, a művészetalapú kutatás és az alkalmazott színház határterületein születnek. A részvételi akciókutatások esetében mindig felmerül a kérdés, hogy az eljárás miféle cselekvéseket és tudást hoz létre, különösen, ha marginális csoportokat is bevon. Oblath szerint - hivatkozva John Law (2004) elméletére - a társadalomtudományos módszerek nem csak reprezentálják a valóságot, hanem világokat teremtve társas cselekvéseket hoznak müködésbe és szabályokat konstruálnak. Igaz ez a résztvevő megfigyelésre is, amikor az erőforrás-hiányos közösségben megjelenő kutató erőforrásként épül be az emberek életébe. Az akciókutatásokban központi kérdéssé válik, hogy miként hozható létre az a kutatási helyzet, amely legitim módon generálja ezen csoportok véleményét. A kortárs társadalmi művészeti kezdeményezések és az akciókutatások közötti kapcsolódást és feszültséget Oblath a kutatások pragmatikus érvényességigényei felől elemezte. A részvételi akciókutatások érvényességigényei közül kiemelte, hogy a kutatásoknak a ciklikusság módszertani szabályait kell követniük, meg kell felelniük a folyamatérvényesség elvének, előre kell jelezniük a folyamat eredményeit - valamint fontos a demokratikusság elve is: a kutatási tevékenységnek a cselekvés legitimitását kell elősegítenie. A múvészetalapú kutatások érvényességigényeit a Baron-Eisner szerzőpáros munkái nyomán mutatta be (Baron-Eisner 1997): a folyamatnak megvilágító hatással kell bírnia, a felvetett problémára fókuszálva célja az újabb és újabb kérdések generálása, ugyanakkor fel kell vetniük, hogy a kutatás eredményei hogyan emelhetők át más kontextusba. A különböző művészeti ágakat bevonó kezdeményezéseikre a részvételi színház készítői társadalmi performanszokként tekintenek, amelyek ri- 
tuális integrációt teremthetnek egy-egy csoport számára, a csoport a részvétel által újrateremtheti saját csoportkohézióját, identitását.

A kritikai cselekvés és tudás dramatikus vizsgálatának egy lehetőségét $A$ hiányzó pillanat című részvételi színházi előadásukkal illusztrálta, amit 2014-15-ben hoztak létre Luc Boltanski (2008) Nuits címú színdarabja átdolgozásával. A menekültekkel való találkozást a középpontba állító játék a résztvevők politikai közösségre vonatkozó képzeteit vizsgálja, és arra kérdez rá, hogy a szolidáris cselekvés miféle repertoárját mozgósíthatja a részt vevő közösség.

Az előadás egy karácsonyt ünneplő családról szól (egy pszichológus, egy szociológushallgató, egy szociális munkás, egy humánerőforrás-menedzser, egy orvosfeleség és egy diáklány alkotják a közösséget), akikhez maga az „ördög, érkezik látogatóba egy állatorvos képében. Az ő segítségével észleli a társaság, hogy a házuktól nem messze egy segítségre szoruló menekült csoport vesztegel. A család addig-addig tervezgeti a menekültek megmentését, amíg késő nem lesz - feltehetően mindannyian meghalnak a kinti fagyban. A részt vevő nézők a történet kiutat jelentő három pillanatát rendezhetik meg, amelyekről egy fotósorozat készül. A kommentált felvételeket a kutatócsoport tagjai a helyi nyilvánosság fórumain is bemutatták, és egyeztetést kezdeményeztek arról is, hogy a darab hat szereplője mennyiben kölcsönözte egy-egy tipikus helyi polgár attitűdjeit. Az előadás így amellett, hogy a lehetséges cselekvésekről egyeztetett a résztvevőkkel, a helyi nyilvánosságban is megpróbálta fenntartani a szolidaritásról szóló diskurzust, mindezt azzal az intencióval, hogy a helyi nyilvánosságban is látható közösség válik a diskurzusban résztvevőkből.

\section{A média terében megjelenő „idegen”}

Az első előadás után Bogdán Mária a színház teréből a média terébe kalauzolta hallgatóit, kutatásaiban a média és kommunikáció által létrehozott társadalmi térben értelmezi a romák társadalmi helyzetét, illetve azt a társadalmi teret, amiben ők helyet foglalnak. Kutatásaiban a dekonstrukciót előtérbe helyező elméletekkel, a posztkolonialista, valamint a kritikai kultúrakutatás és reprezentáció nyelvészeti megközelítéseivel dolgozik (többek közt: Gayatri Chakravorty Spivak, Edward Said, Ann Marie Fallon, Jacques Derrida munkáit veszi alapul).

Derrida (2004) vendégszeretet-diskurzusából kiindulva az „idegent” a társadalmi térben létrejövő viszonyrendszerként képzeli el. Sajátos multidiszciplináris megközelítéssel arra törekszik, hogy leírja, milyen lélektani távolságot teremt a média diskurzusa; azt a lélektani folyamatot szeretné megragadni, amely kijelöli a romák társadalmi helyzetét, létrehozza az idegent és viszonyrendszerét, továbbá azt is vizsgálja, hogy ez a viszonyrendszer milyen folyamatok során képes változni. Hipotézise szerint - amit előadásában idő hiányában elnagyoltan mutatott be - a médiareprezentáció a romákat újra és újra az idegen státuszába helyezi. 
Bemutatott kutatásában a közösségi terekben létrejövő roma polgárjogi mozgalmakat vizsgálta, és azt, hogy ezek a mozgalmak hogyan képesek létrehozni a nyilvánosság új tereit. Arra volt kíváncsi, hogy a többségi társadalom által felkínált egzotikus vagy sztereotip romaképek ellenében meg tudják-e teremteni ezen fórumok által a romák saját identitásukat, amellyel azonosulni tudnak. Továbbá, hogy képesek-e pozitív identitáskonstrukciókat létrehozni, képes-e a közösségi média tere a „visszabeszélés” terévé válni. A „visszabeszélés terét” Ian Hancock (2010) munkája nyomán értelmezi, aki szerint a romákról kialakított tudás és az identitás, amellyel azonosulnak, toolük függetlenül jött létre, így ennek megváltoztatásához nekik maguknak is bele kell szólniuk a róluk szóló tudás megteremtésébe. Az említett kérdés különösen égetővé vált a 2008-as romagyilkosságok kapcsán, ugyanis a nyilvánosság tereiben a témát csönd övezi. Felmerül azonban a kérdés, hogy a felkínált médiareprezentációk helyett milyen más identitásokat tudnak ezekben a terekben megkonstruálni, és vajon a „szuperhős” vagy a „hétköznapi hősök” karakterei segítenek-e mindebben. A hős narratívája vajon nem termeli-e újra az idegen pozícióját azáltal, hogy a hős arra hivatott, hogy véghez vigye fontos küldetését, majd eltűnjön? Későbbi kutatásaiban Bogdán Mária a hétköznapi hősökkel és a velük azonosulókkal, illetve a hírek olvasóival készül interjúkat felvenni.

\section{Áldozatpolitika a színházban}

Horváth Kata előadásával mindkét előtte elhangzó prezentációhoz kapcsolódott Oblath Mártonnal közösen vezetik a SajátSzínház projektjeit, illetve Bogdán Máriához is hasonló kutatási kérdései miatt. Horváth Kata a Káva Kulturális Mühely Szobor címú előadásáról beszélt, pontosabban azokról az alakításokról, amelyeket a színházi nevelési előadás egyik eseményén egy roma csoport hozott a színházi térbe. Elsőként az áldozatpolitika által felvetett komplex kérdéseket ismertette, és kiemelte, hogy az angol 'victimhood' fordításaként értelmezi az 'áldozatiság'-ot. Elméletét Steffen Jensen és Henrik Ronsbo (2014) Histories of Victimhood című könyve alapján ismertette, akik az áldozatpolitika három megközelítését különítik el. Az első kérdés, ami felmerülhet a politika kapcsán, geneológiai: a diszkurzív hatalmi múködések különböző időszakokban és terekben hogyan hoznak létre áldozatokat, és ez milyen következményekhez vezet. A tranzakcionalista megközelítés a különböző színtereken létrejött diskurzusok egymásra hatásával foglalkozik, míg a terephez kötött (grounded) áldozatfelfogás azzal foglalkozik, hogy a konkrét helyzetek konkrét szereplői hogyan fogalmazzák meg áldozatiságukat, vagy megfogalmazzák-e azt egyáltalán. Sokszor megfigyelhető ugyanis, hogy az áldozatok nem tudnak áldozatpolitikát létrehozni, csupán helyzeteket, amelyekben a szenvedés önellentmondásos szövegei születhetnek meg. Az áldozatipolitika megkonstruálása valójában már feltételez egy politikai közösséget. 
A Szobor című színházi nevelési előadás a romagyilkosságok után született, és a történtekre való emlékezés kérdését járta körbe. A történetben a falu polgármestere egy szobrot kap, amely egy meggyilkolt roma fiúnak, Varga Lacinak állít emléket. A polgármester eldugja a fôvárosi szobrászmúvész alkotását, de a veje kicsempészi, a részt vevő diákok pedig a falu lakóinak szerepét felvéve dönthetnek, hogy felállítsák-e a szobrot a faluban. A szomolyai és sályi roma fiatalokat bevonó 2016-os előadáson a résztvevőkről kiderült, hogy nem hallottak még a 2008-as romák elleni gyilkosságokról, és azzal kapcsolatos viták is kialakultak, hogy ebben a történetben a romák áldozatok-e vagy elkövetők. A fiatalok az előadás több pontján megkérdőjelezték a szobor felállításának szükségességét, és azzal sem értettek egyet, hogy ha már felállítják, miért éppen a főtéren, és miért nem inkább a temetőben helyezik azt el. A roma diákok „kivételezésnek” tartották a roma fiú emlékére állított szobrot:

„Drámatanár: Most azt is hallom a hangodban, hogy akkor ezt lehet, nem kellett volna kirakni a fötérre.

Diák 1: Hát nem.

Drámatanár: De miért?

Diák 1: Mert attól, hogy egy embert megöltek, attól nem kell szobrot csinálni. Most azért, mert hogy ő cigány, azért nem kell neki szobrot csinálni.

Diák 2: Mert az emberek azt fogják gondolni, hogy kivételeznek a Lacival. Kivételezésnek fogják gondolni."

A vita után éppen fele-fele arányban szavaztak a résztvevők a felállítás mellett és ellen, az így kialakuló cselekvésképtelenséget nem tudták feloldani. A diákok nem tudtak megegyezni abban, hogy a romák ellen elkövetett gyilkosság emlékezésre érdemes esemény-e: nem csak az vált kérdéssé, hogy hasznos-e, veszélyes-e a roma közösségre nézve az emlékállítás, hanem a cigányokkal szembeni provokációként fogták fel a szobrot, minthogy a más körülmények között elhunyt, nem cigány áldozatoknak nem állítottak emléket a fiktív történetben. A kérdés továbbgondolására érdemes az a momentum is, hogy a történetben egy fővárosi szobrászművész, vagyis egy külső szereplő indította el az áldozatiságról szóló diskurzust. A tekintélyszemély elismerése ez esetben nem eredményezte az áldozatiság felismerését.

\section{Egy megemlékezés margójára}

Lénárt András a 2014 júniusában megszervezett „Csillagos házak” projekt néhány akcióját mutatta be előadásában. Az Open Society Archive 2014 januárjában kezdte el a júniusi akciók tervezését, ekkor hozták létre többek között a projekt honlapját is, amelyen szerepel például az egykori 2000 csillagos házból ma is álló 1300 ház. A Horthy Miklós kormányzóságának idején kiadott június 21-i rendelet a fővárosi zsidóságot lakhelye elhagyására és a kijelölt csillagos házakba költözésre kényszerítette. A határozat kb. 220.000 embert érintett. A 2014-es akció (éppen 70 évvel később) ugyanazon a napon emlékezett meg a fóvárosi zsidóság egyik traumatikus élményé- 
ről. Az akciót azért is tartották fontosnak szervezői, mert a csillagos házak léte kevés hangsúlyt kap a holokauszt emlékezetében.

A szervezők több megelőző akcióban hívták fel a házak jelenlegi lakóinak figyelmét a közelgő eseménysorozatra, így ők is a programok szervezőivé, alakítóivá válhattak. Június 21-én több ismert személyiség- köztük Alföldi Róbert, Mautner Zsófia, Korda György - is részt vett a megemlékezésen, a legváltozatosabb megemlékezési formát választva: voltak, akik a haláltáborban megtalált szakácskönyvből főztek és olvastak fel recepteket; míg mások jiddis dalokkal emlékeztek. Lénárt András több fontos kérdést is felvetett az akciókkal kapcsolatban: mik azok az emlékezésformák, amelyek közösséget teremthetnek; mikortól lehet egy gyereket bevonni mindebbe; hogyan emelhető a közterek nyilvánosságába a kommunikatív emlékezet?

A program nem ismétlődött meg, habár a szervezők szerették volna, ha emléknap válik június 21-ből. Az itthoni megemlékezés az utcai színterekkel sokkal inkább tiltakozásjelleget öltött, nem véletlenül: a kormány által a 70. évfordulóra létrehozott Emlékbizottság több fronton is összetúzésbe került a Magyar Zsidó Hitközséggel, így a kormánytól független szervezetek is létrehozták a maguk megemlékezéseit, amelyeket a Memento70 nevű kezdeményezés finanszírozott. Talán a kulturális emlékezés (Assmann 2004) körül kialakult viták vezettek oda, hogy nem sikerült a közösen létrehozott programokat rendszeressé tenni: nem vált az egyszeri megemlékezés a házakban lakó közösségek kommunikatív emlékezetének részévé.

\section{Az előadásokhoz kapcsolódó kérdések}

Az előadások utáni kérdések egy része a közös projektben dolgozó Horváth Katához és Oblath Mártonhoz szólt, másrészt a szintén két előadás által is érintett cigány identitáshoz kapcsolódott. Az első kérdés arra vonatkozott, milyen értelemben definiálja a SajátSzínház az akcióit kutatásként. Oblath Márton szerint társadalomtudományos értelemben is beszélhetünk kutatásról, a dilemma inkább az, hogy a társadalomtudományos közlemény, vagy előadás miként következik a folyamatból. Milyen igényt elégít ki a tudományos performansz formája és annak jelentései miként illeszkednek a folyamattal kapcsolatos pragmatikus érvényességigényekhez? Például a közösen összerakott vizuális megjelenítés esetében - ami a résztvevők számára új tudást termelve részvételi kutatásként értelmezhető - nem termel-e legitimációs deficitet, ha csupán egy utólagos, a társadalomtudományos nyelvre történő átfordítás következik be. Horváth Kata szintén ezt az állásponton képviselve hangsúlyozta, hogy számukra minden új tudást termelő folyamat - legyen az egy videó készítése, egy színházi előadás vagy konferenciabeszélgetés megszervezése - kutatás, hiszen ami ott történik, az nem más, mint folytonos egyeztetés a körülöttünk lévő világról. Ez a dilemma ráadásul nem csak a társadalomtudományos mezőben jelentkezik egy múvészet alapú akciónál. A színházi előadások esetében az esztétikum kérdése is megjelenik, az előadásoknak a színházi mező esztétikájának is meg kell felelniük. 
A későbbi kérdések szintén Horváth Katának szóltak, akitől Bogdán Mária azt kérdezte, megvolt-e a színházi előadásba bevont roma nőknek a lehetőségük arra, hogy önmagukat definiálják romaként, vagy ez a kutatók meghatározása által létrejött csoportképző elem volt. Horváth Kata elmondta, hogy a Szívhangok című projektjükbe bevont nők nem romaként lettek megszólítva - az előadás az egészségügy témáját dolgozta fel, ám a faluban tapasztalható viták nyomán végül az a helyzet állt elő, hogy csak roma nők vettek részt az előadásban. A program bizonyos pontjain így ők maguk kezdték el boncolgatni azt, hogy a témához miként kapcsolódik roma mivoltuk.

\section{A város aktivista társadalomkutatói}

A „Társadalomkutatók a városban: aktivizmus és kutatás” címmel megtartott kerekasztal résztvevői arról egyeztettek, hogy az akadémiai közegben is otthonosan mozgó aktivista kutatók hogyan egyeztetik össze kutatói és aktivista identitásukat, és ez a két nézőpont hogyan tudja kiegészíteni egymást. A meghívott vendégeket módszerükön túl az is összeköti, hogy mindannyian a városi térrel foglalkoznak kutatásaik során. A kerekasztal résztvevői voltak: Jelinek Csaba, a Kritikai Városműhely alapító tagja, városszociológus, az MTA Regionális Kutatások Központja munkatársa; Udvarhelyi Tessza kulturális antropológus és környezetpszichológus, aki doktori tanulmányai során a részvételi akciókutatással foglalkozott, jelenleg pedig a Város mindenkié aktivistája és a Közélet Iskolája munkatársa; Cseke Balázs a „Város peremén” projekt önkéntese, társkoordinátora, aki elsőéves kommunikáció és média mesterszakos hallgató az ELTE Bölcsészettudományi Karán; Kelen Zsuzsa a „Város peremén” projekt önkéntese, aki az ELTE kisebbségpolitika mesterszakán végzett; Kóczé Angéla szociológus, aki aktivistaként és kutatóként is részt vesz olyan projektben, amelyek a nemek és etnicitás, valamint a társadalmi osztályok összefüggéseit vizsgálja; és Bálint Mónika szociológus, aki 2001 óta vesz részt különböző civil szervezetek munkájában, jelenleg közösségszervező mentor és tréner a Civil Kollégium Alapítványnál. A beszélgetést Kerényi Szabina moderálta.

Jelinek Csaba a 2010 óta fennálló Kritikai Városmühely munkáját mutatta be. A 8-10 aktív tagot tömörítő szervezet a Corvinus Egyetem Társadalomelméleti Kollégiuma olvasóköréből kinőve jelenleg informálisan múködik. Feladatukat az akadémiai tudástermelés, a közpolitikai döntéshozás és az aktivizmus szférái közötti kommunikáció segítésében látják. Jelinek Csaba úgy gondolja, hogy nincs objektív tudományos nézőpont, döntéseikhez mindig valamilyen értékvállalás kapcsolódik, így céljukban is állást foglalnak: a társadalmi egyenlőtlenségek ellen szeretnének tenni. Mindezt egy progresszív közpolitika létrehozása garantálhatná, ennek és a három említett szféra kommunikációjának javításán dolgoznak a helyi és nemzetközi kontextus figyelembevételével.

Udvarhelyi Tessza kulturális antropológusként beszélt a kerekasztalon, ahol megosztotta saját aktivista tapasztalatait is. 2002-ben a hajléktalanságról írt szakdolgo- 
zata írásakor érezte úgy először, hogy nem csak leírni akarja, de változtatni is szeretne a jelenlegi társadalmi viszonyokon. Érdeklődése dühhel vegyült, ez az indulat indította el aktivista pályáján. Mindeközben az akadémiai szférát sem hagyta el, hiszen New Yorkban ledoktorált. A Város mindenkiért aktivistájaként a szervezetről elmondta, hogy a lakhatási szegénység strukturalista egyenlőtlenségeivel foglalkoznak szintén több szféra közt lavírozva aktivista tevékenységük mellett közérdekű adatokkal is dolgoznak, mert úgy látják, tevékenységüket csak így tudják legitimálni az akadémiai szféra felé.

Cseke Balázs és Kelen Zsuzsa a Város peremén projektet mutatták be, amely emlékezetkutatásként fogható fel: a Mérei Ferenc Szakkollégiummal és az ELTE Angelusz Róbert Társadalomtudományi Szakkollégiummal közösen megkezdett kutatásukban a „Dzsumbujnak” nevezett városrész emlékezetével foglalkoztak. A kutatás megkezdésekor az akadémiai tudást felhasználva gyüjtöttek ismereteket, de projektjük során az aktivizmus is fontos szerepet kapott. A volt lakók közül néhány fiatalt sikerült a kutatási folyamat aktív részesévé tenni, az elért eredményeket pedig minden esetben a lakóközösség nyilvánosságát bevonva prezentálták. Céljuk az volt, hogy olyan közérthető produktumokat (kiadványok, kiállítás, kerekasztal-beszélgetés) hozzanak létre, amelyekből bárki profitálhat, és amelyek segítenek a „Dzsumbujról” kialakított kép árnyalásában.

Kóczé Angéla a 2009 és 2011 közt megvalósult szikszói kutatásáról mesélt, ahol a Magyar Gárda ellen szerveződő roma nők mozgalmát vizsgálta. Mivel kutatásai során kritikai posztkolonialista és feminista elméteket használ, a többi vendéghez hasonlóan ő sem hisz az objektív tudományosságban. Emellett úgy látta, hogy a kutatók nem informálják a kutatott közösségeket eredményeikről, így számára egyértelmű volt, hogy részvételi kutatással szeretne foglalkozni. Bemutatkozásában arra is reflektált, hogy roma szociológusként problematikusnak tartotta pozícióját, úgy érezte, hogy a romák sokkal inkább a kutatott közösség szerepében jelennek meg, nem kutatóként. Ez az élménye munkáinak és választott módszerének is a katalizátora.

Bálint Mónika doktori disszertációjában is a részvételiség fogalmát kutatta: azt vizsgálta, hogy különböző részvételi művészeti projektekben hogyan valósul meg a múvészek, a társadalomtudósok és a bevont résztvevők közremúködése. Aktivista tevékenységének központi elemét alkotják az „éntörténetek”, amelyekkel a kiszolgáltatott csoportok is kifejezhetik álláspontjukat, illetve ugyanilyen fontos szerepet tölt be a múvészet - több művészeti akciókutatás résztvevője is volt. Emellett az akadémiai tudás produktumait is felhasználja kutatótevékenységei során.

A következő körkérdés a tudományos tudástermelés és az aktivizmus egymásra hatására vonatkozott. Jelinek Csaba kifejtette, hogy tevékenységük főképp ez utóbbiból áll, mivel elsősorban könyvszerkesztéssel, előadások és workshopok szervezésével foglalkoznak, ám a két terület közelebbi viszonyának elősegítése munkájuk célja. Meglátása szerint mindkét szféra erőforráshiánnyal küzd, ám az akadémiai közegnek lenne a feladata, hogy kereteket és koncepciókat nyújtson az aktivista tevékenység 
számára. A két szféra egymás nélkül nem tud múködni. Udvarhelyi Tessza azt emelte ki, hogy amikor 2004-2006 tájékán elkezdett az aktivizmus felé fordulni, a két terület még élesen elhatárolódott egymástól, ebben azonban az utóbbi időben változás történik. A mostanában megfigyelhető közeledés viszont még kevés, mivel az akadémiai közeg erősen zárt, osztálykülönbségektől terhelt, és hiába a nyitás, ha a terek változatlanul zártak maradnak és a létrejött tudás nem válik közérthetővé. Kelen Zsuzsa és Cseke Balázs projektjük kapcsán elmondták, hogy tudományos tudás nélkül nem valósulhatott volna meg a kutatásuk, és habár kezdetben nem volt céljuk az aktivista tevékenység, az egyenlőtlenség csökkentésének szándéka végül aktivizmusként is felfogható tevékenységhez vezetett. Munkájuk fontos eredményének tartják, hogy olyan nyilvános tereket hoztak létre, ahol különböző osztályhelyzetű és különböző kulturális tőkével rendelkező embereket egy asztalhoz tudtak ütetni. Kóczé Angéla az előző hozzászólókat erősítve a roma kutatók hiányával szemléltette az akadémiai közeg zártságát, és nehezményezte azt is, hogy a szakpolitikai döntéshozással foglalkozó kutatókat sem ismeri el megfelelőképpen a tudományos mező.

Abban minden vendég egyetértett, hogy a tudományos tudás és az aktivista tevékenység együtt valósulhat meg, mindehhez pedig elsősorban a keretek átírására van szükség. Az előző előadásokra visszautalva a színház például egy olyan újfajta nyilvánosságot jelenthet, ahol az akadémiai tudás és az aktivista tenni akarás együtt is megjelenhet.

\section{Irodalom}

Assmann, J. (2004): A kulturális emlékezet. Irás, emlékezés és politikai identitás a korai magaskultúrában. Budapest: Atlantisz Könyvkiadó

Barone, T. - Eisner, E. (1997): Arts-Based Educational Research. Complementary Methods For Research. Education, 2: 75-116.

Boltanski, L. (2008): Nuits. Lyon: ENS Editions.

Derrida, J. (2004): Az idegen kérdése: az idegentől jött. In Biczó G. (szerk.): Az idegen: Variációk Simmeltől Derridáig. Debrecen: Csokonai Kiadó,11-29.

Hancock, I. (2010): Talking Back. In Karanth, D. (ed.): Danger! Educated Gypsy. Selected Essays. Hatfield: University of Hertfordshire, 38-44.

Jensen, S. - Ronsbo, H. (2014): Histories of Victimhood. Philadelphia: University of Pennsylvania Press.

Law, J. - Urry, J. (2004): Enacting The Social. Economy and Society, 33(3): 390-410. 